\title{
Effect of Minimal Enteral Feeding on Splanchnic Uptake of Leucine in the Postabsorptive State in Preterm Infants
}

\author{
MIGUEL SÁENZ DE PIPAÓN, RON H.T. VANBEEK, JOSÉ QUERO, JESÚS PÉREZ, \\ DARCOS J.L. WATTIMENA, AND PIETER J.J. SAUER \\ Neonatology Unit, La Paz University Hospital, Autónoma University of Madrid, Madrid, Spain [M.S.d.P., \\ J.Q., J.P]; Department of Pediatrics, Amphia Hospital Breda, Breda, The Netherlands [R.H.T.V.]; \\ Internal Medicine II, Erasmus University Rotterdam, Rotterdam, The Netherlands [D.J.L.W.]; \\ Department of Pediatrics, Beatrix Children's Hospital, University Hospital Groningen, Groningen, \\ The Netherlands [P.J.J.S.]
}

\begin{abstract}
We conducted a controlled, randomized trial to study the effect of minimal enteral feeding on leucine uptake by splanchnic tissues, as an indicator of maturation of these tissues, in preterm infants in the first week of life. Within a few hours after birth, while receiving only glucose, a primed constant infusion of $\left[1-{ }^{13} \mathrm{C}\right]$-leucine was started and continued for $5 \mathrm{~h}$ via the nasogastric tube, whereas 5,5,5 D3-leucine was infused intravenously (for both tracers, priming dose $2 \mathrm{mg} / \mathrm{kg}$, continuous infusion 2 $\mathrm{mg} / \mathrm{kg} / \mathrm{h}$ ). Patients were thereafter randomized to receive solely parenteral nutrition (C), parenteral nutrition and $20 \mathrm{~mL}$ breast milk/kg/d (BM), or parenteral nutrition and $20 \mathrm{~mL}$ formula/kg/d (F). On d 7, the measurements were repeated, after discontinuing the oral intake for $5 \mathrm{~h}$. Fourteen infants were included in group C, 12 in group BM, and 12 in group F. There was no difference in energy intake or nitrogen balance at any time. On $\mathrm{d} 1$, plasma enrichment for the nasogastric tracer was lower than for the intravenous tracer for all three groups, both for leucine and for $\alpha$-keto-isocaproic acid. On d 7, the enrichment for leucine and
\end{abstract}

\section{ABSTRACT}

$\alpha$-keto-isocaproic acid for the nasogastric tracer was lower than for the intravenous tracer for the groups BM and F (BM: $3.65 \pm$ 1.20 nasogastric versus $4.64 \pm 0.64$ i.v.; F: $4.37 \pm 1.14$ nasogastric versus $5.21 \pm 0.9$ i.v.). In the control group, there was no difference between tracers. The lower plasma enrichment for the nasogastric tracer compared with the intravenous tracer suggests uptake of leucine by the splanchnic tissues. We conclude that minimal enteral feeding - even in low volumes of $20 \mathrm{~mL} / \mathrm{kg} / \mathrm{d}$ increases the leucine uptake by the splanchnic tissue. We speculate that this reflects a higher protein synthesis of splanchnic tissues in the groups receiving enteral nutrition. (Pediatr Res 53: 281-287, 2003)

KIC, $\alpha$-keto-isocaproic acid

VLBW, very low birth weight

$\mathbf{Q}_{\mathbf{L}}$, Plasma leucine flux

GI, gastrointestinal
Advances in perinatal care have lead to a significant increase in survival of preterm infants. There has been an increasing recognition that nutrition plays an important role in the survival and subsequent growth and development of VLBW infants. Parenteral nutrition is used extensively in clinical care of preterm infants. The timing of initiation of enteral feeding in VLBW infants is still controversial. On one hand, anxiety about necrotizing enterocolitis has prompted neonatologists to delay enteral feeding in VLBW infants. On the other hand,

Received June 18, 2001; accepted June 4, 2002.

Correspondence: M. Saenz de Pipaón, Servicio de Neonatología, Hospital Universitario La Paz, Paseo de la Castellana 261, Madrid 28046, Spain; e-mail: PIPAON@ santandersupernet.com

Supported by grants BAE 96/5234, BAE 97/5188, FIS 98/1101 from the Spanish National Institute of Health

DOI: 10.1203/01.PDR.0000047519.22873.3F animal studies have shown a negative effect of replacing enteral with total parenteral nutrition on gut morphology and function (1-5). Minimal enteral feeding has been shown to improve gut maturation, as evidenced by improved motility $(6,7)$.

The effect of minimal enteral feeding on protein metabolism of splanchnic tissues, an indicator of anabolism of splanchnic tissues, is unknown. Recently, a model using stable isotopes was described that measures the uptake of leucine administered to the GI tract by splanchnic tissues $(8,9)$. In adult human subjects, $17-25 \%$ of orally administered leucine is removed by the splanchnic tissues on first pass $(8,10,11)$. Studies show that $13-40 \%$ of the leucine was released as KIC to the systemic circulation $(11,12)$. The fraction of dietary leucine disappearing within the splanchnic region increased from approximately $21 \%$ to approximately $40 \%$ when decreasing the leucine intake from 40 to $10 \mathrm{mg}$ in adult volunteers (13). Cayol et al.(14) 
studied the difference between the effects of protein and protein-free nutrition on the splanchnic leucine kinetics. The splanchnic uptake of leucine was 2.1 times higher in the group receiving protein. The extent of splanchnic uptake varies among the different amino acids. Studies in adults showed that $40 \%$ of the leucine appearing in plasma is derived from intestinal sources, compared with $20 \%$ for phenylalanine (10). The splanchnic uptake of amino acids might also be different for patients of different ages. In infants and elderly men, the splanchnic extraction is two times as high as in adults $(9,15)$. The effect of enteral feeding on the splanchnic leucine uptake in newborns is unknown.

We conducted a controlled, randomized trial to study the effect of minimal enteral feeding, either as breast feeding or formula, on the leucine uptake of splanchnic tissues in preterm infants in the first week of life. We hypothesized that minimal enteral feeding improves maturation of splanchnic tissue as evidenced by an increased leucine uptake.

\section{METHODS}

Patients. Patients admitted to the neonatal intensive care unit at $\mathrm{La} \mathrm{Paz}$ University Hospital with a birth weight of $<1600$ g were included. Gestational age was calculated from maternal history or, in case of uncertainty, estimated from the Ballard score (16). Patients were considered appropriate for gestational age if weight was within $2 \mathrm{SD}$, according to the chart of Usher and McLean (17). Exclusion criteria were infants of diabetic mothers, major congenital anomalies, or proven sepsis. Infants were scored according to the clinical risk index for babies (CRIB) scoring system (18).

The feeding policy, at the time of the study, was to delay enteral feeding after birth in infants admitted to the neonatal intensive care unit. Instead, on d 1, parenteral nutrition including amino acids and lipids was started in infants with a birth weight $<1600 \mathrm{~g}$. For this study, infants were divided into three groups. One group receiving no enteral feeding served as controls (group C). In two other groups, minimal enteral feeding was started on $\mathrm{d} 1$. Feeding started with $10 \mathrm{~mL} / \mathrm{kg} / \mathrm{d}$ on $\mathrm{d} 1$, increasing to $20 \mathrm{~mL} / \mathrm{kg} / \mathrm{d}$ from d 2 through $\mathrm{d} 7$. One group received formula feeding (Nenatal, Nutricia, Zoetermeer, The Netherlands) (group F), whereas the other group received milk from their own mother (group BM). Infants were, at random, assigned to minimal enteral nutrition or no enteral nutrition for the first week of life. Infants assigned to minimal enteral nutrition and whose mothers intended to breast feed were included in group BM. Weight was measured at the same time each day using a balance accurate to $5 \mathrm{~g}$ (Digital Baby Scale, model DS-30A Kubota LTD, Osaka, Japan). Length was measured with a flexible, nonstretch, plastic-coated tape. The study was approved by the Ethical Committee of the Medical Faculty, Erasmus University Rotterdam, The Netherlands, and the University Hospital La Paz, Madrid, Spain. Written consent was obtained from at least one of the parents.

Experimental design. Twenty-four-hour intake of calories, nitrogen, and fluid were determined from $\mathrm{d} 1$ to 7 . Nitrogen intake was calculated from the nitrogen content of products used provided by the producer. Measurement of 24-h nitrogen balance was carried out by collection of urine in three hourly periods using adhesive bags on $\mathrm{d} 1$ and 7. All feces and vomitus were collected on both study days. An outline of the study design is given in Figure 1.

For the isotope studies, on $\mathrm{d} 1$ and 7 , a primed constant intravenous infusion of $\mathrm{NaH}^{13} \mathrm{CO}_{3}$ (priming dose $7 \mu \mathrm{mol} / \mathrm{kg}$, continuous infusion $3.5 \mu \mathrm{mol} / \mathrm{kg} / \mathrm{h}, 98.7 \%$ enriched, Isotech, Miamisburg, OH, U.S.A.) was administered for $3 \mathrm{~h}$ using a Harvard infusion pump (M22, Harvard Apparatus, S. Natick, MA, U.S.A.). After the infusion of ${ }^{13} \mathrm{C}$-labeled sodium bicarbonate, a primed constant infusion of labeled leucine was started and continued for $5 \mathrm{~h}$ both intravenously and via the nasogastric (ng) tube. $1-{ }^{13} \mathrm{C}$ leucine (99\% enriched, Isotech) was infused via the tube (priming dose $2 \mathrm{mg} / \mathrm{kg}$, continuous infusion $2 \mathrm{mg} / \mathrm{kg} / \mathrm{h}$ ), whereas 5,5,5 D3-leucine (99\% enriched, Isotech) was infused intravenously (priming dose $2 \mathrm{mg} / \mathrm{kg}$, continuous infusion $2 \mathrm{mg} / \mathrm{kg} / \mathrm{h}$ ). On d 1, the isotope study was conducted before starting the enteral feeding. On $d 7$, minimal enteral feeding was stopped $5 \mathrm{~h}$ before the start of the isotope infusion.

Expired air was collected before and during the isotope infusion by passing a sample of air leaving the ventilator through an all-glass spiral condenser, containing $10 \mathrm{~mL}$ of a fresh $1 \mathrm{M} \mathrm{NaOH}$ solution. After liberating $\mathrm{CO}_{2}$ by adding phosphoric acid (85\%) to the solution, the ${ }^{13} \mathrm{CO}_{2} /{ }^{12} \mathrm{CO}_{2}$ isotope ratio was measured on an isotope ratio/mass spectrometer. If the infant did not have an endotracheal tube, expired $\mathrm{CO}_{2}$ was collected by a mask placed over the mouth and nose.

Four blood samples were drawn, one before the start of the leucine infusion and three at the end of leucine infusion, with a 15 -min interval (19). Within $15 \mathrm{~min}$, plasma was stored at $-70^{\circ} \mathrm{C}$ until further analysis

Analytical methods. Total nitrogen concentrations in the 3-h urine samples were determined by an automatic nitrogen analyzer (ANA 1400, Carlo Erba, Milan, Italy).

In this study, both leucine and KIC were measured. Leucine is reversibly transaminated to KIC. KIC is a reflection of intracellular leucine enrichment. One hundred microliters of plasma were deproteinized by adding $250 \mu \mathrm{L}$ sulfosalicylic acid $(6 \%)$, after the addition of the internal standards ketocaproic acid, ketovaleric acid, and norleucine. A rapid cation-

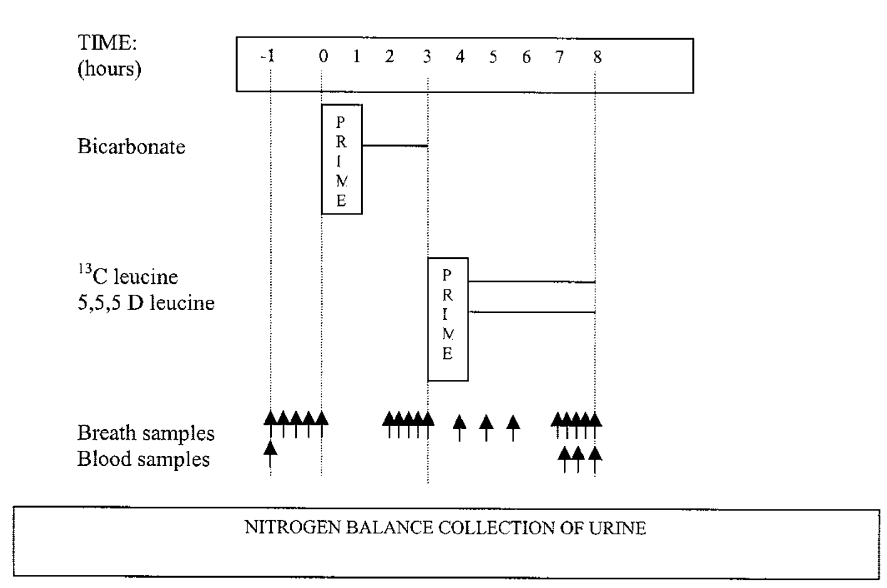

Figure 1. Outline of the isotope study design. 
exchange chromatographic procedure was used to isolate KIC and the amino acids by passing the mixture through a small column $(2 \mathrm{~cm} \times 7 \mathrm{~mm}$ internal diameter $)$ of AG $50 \mathrm{~W}$-X8 resin (SPE tubes, Supelco, Bellefonte, PA, U.S.A.), eluting KIC with $\mathrm{HCl}(0.01 \mathrm{~N}, 1 \mathrm{~mL})$ and the amino acids with distilled water $(2$ $\mathrm{mL}$ ) followed by ammonia $(4 \mathrm{M}, 2 \mathrm{~mL})$.

KIC was derivatized by adding freshly prepared ophenylenediamine solution $(2 \%$ in $6 \mathrm{M} \mathrm{HCl}, 0.5 \mathrm{~mL})$ at $100^{\circ} \mathrm{C}$ for $1 \mathrm{~h}$. The solution was extracted with methylene chloride:hexane $(1: 1,1.8 \mathrm{~mL})$ and dried under nitrogen at $45^{\circ} \mathrm{C}$. The residue was dissolved in methylene chloride, dried under nitrogen, and reacted with N-methyl-N-(tert-butyldimethylsilyl) trifluoroacetamide (MTBSTFA) $(0.05 \mathrm{~mL})$ at room temperature for $30 \mathrm{~min}$.

Amino acids were derivatized to their t-butyldimethylsilyl derivatives. The effluent was dried under nitrogen at $70^{\circ} \mathrm{C}$. Methylene chloride $(0.5 \mathrm{~mL})$ was added to the residue. After evaporation of the solvent at room temperature under nitrogen, the residue was dissolved in pyridine $(0.02 \mathrm{~mL})$ and reacted with MTBSFTA $(0.02 \mathrm{~mL})$ at $60^{\circ} \mathrm{C}$ for $1 \mathrm{~h}$.

Gas chromatography/mass spectrometry was carried out on a Hewlett Packard HP 5890 (Palo Alto, CA, U.S.A.) gas chromatograph coupled to a JEOL JMS-DX303 (Tokyo, Japan) mass spectrometer operating in the electron impact mode. Chromatography was carried out on a $25 \mathrm{~m} \times 0.32 \mathrm{~mm}$ capillary column (CP-Sil5-CB, Chrompack BV, Middelburg, The Netherlands). Selective ion monitoring was carried out at $\mathrm{m} / \mathrm{z} 259,260$, and 262 for $\mathrm{KIC},\left[{ }^{13} \mathrm{C}\right] \mathrm{KIC}$, and $\left[\mathrm{D}_{3}\right] \mathrm{KIC}$, respectively; and at $\mathrm{m} / \mathrm{z} 302,303$, and 305 for leucine, $\left[{ }^{13} \mathrm{C}\right]-$ leucine, and $\left[\mathrm{D}_{3}\right]$-leucine, respectively.

Calculations. Previous studies from this and many other laboratories have used a steady-state, whole body model of amino acid metabolism $(19,20)$. This model assumes a common "metabolic" amino acid pool through which all amino acids move, either to enter from the diet or protein breakdown or to exit for protein synthesis or oxidative catabolism. Plasma leucine fluxes, $\mathrm{Q}_{\mathrm{L}}$, were calculated from plasma enrichment levels for both nasogastric and intravenous tracers with the equation $\mathrm{Q}_{\mathrm{L}}=\mathrm{I} \times\left[\left(\mathrm{E}_{\mathrm{i}} / \mathrm{E}_{\mathrm{p}}\right)-1\right] \mu \mathrm{mol} / \mathrm{kg} / \mathrm{h}$, where I is the rate of leucine tracer infusion $(\mu \mathrm{mol} / \mathrm{kg} / \mathrm{h})$ and $E_{i}$ and $E_{p}$ are isotopic enrichments of the tracer infused and of the tracer in plasma. Calculations were also performed with the reciprocal pool model by substituting KIC to leucine enrichment.

Assuming a constant pool size, leucine leaving the pool [for protein synthesis (nonoxidative leucine disposal, NOLD) and oxidation $(\mathrm{O})$ ] should equal leucine entering the pool [from dietary intake $\left(\mathrm{I}_{\text {leu }}\right)$ and from protein breakdown (leucine released from proteins, LRP)]. In the equation $\mathrm{Q}_{\mathrm{L}}=\mathrm{I}_{\text {leu }}+\mathrm{LRP}$ $=\mathrm{O}+\mathrm{NOLD}$, leucine oxidation was calculated by multiplying the recovery of the label in expiratory air with the flux of leucine, based on plasma $\left[{ }^{13} \mathrm{C}\right] \mathrm{KIC}$. The recovery of the label in expiratory air was measured according to the following equation, assuming a constant rate of excretion of $\mathrm{CO}_{2}$ during the study: $\operatorname{Rec}=\left(\mathrm{Ie}_{\mathrm{L}} \times \mathrm{I}_{\mathrm{B}}\right) /\left(\mathrm{IE}_{\mathrm{B}} \times \mathrm{I}_{\mathrm{L}}\right)$, where $\mathrm{Ie}_{\mathrm{L}}$ is the ${ }^{13} \mathrm{CO}_{2}$ enrichment at plateau during the $\left[{ }^{13} \mathrm{C}\right]$-leucine infusion, $\mathrm{IE}_{\mathrm{B}}$ is the ${ }^{13} \mathrm{CO}_{2}$ enrichment at plateau during the $\mathrm{NaH}^{13} \mathrm{CO}_{3}$ infusion, $\mathrm{I}_{\mathrm{L}}$ is the infusion rate of $\left[{ }^{13} \mathrm{C}\right]$-leucine in $\mu \mathrm{mol}{ }^{13} \mathrm{C} / \mathrm{kg} / \mathrm{h}$ and $\mathrm{I}_{\mathrm{B}}$ is the infusion rate of $\mathrm{NaH}^{13} \mathrm{CO}_{3}$ in $\mu \mathrm{mol}{ }^{13} \mathrm{C} / \mathrm{kg} / \mathrm{h}$.

A fraction of the nasogastrically infused tracer may be removed in splanchnic tissues before reaching the plasma. We calculated this quantity from the difference between the plasma enrichment of the nasogastric tracer and the intravenous tracer.

The leucine extraction by the splanchnic tissues was also calculated according to Beaufrère et al. (9).

Statistical analysis. Mean plateau enrichment values were used to calculate substrate flux values as noted above. Data were analyzed with Graph Prism Software (GraphPad Software, San Diego, CA, U.S.A.). The three groups were compared with the use of one-way ANOVA, with Bonferroni test for pair-wise comparison, and $\chi^{2}$ test for analysis of contingency tables. Differences, within each group, from birth to $\mathrm{d} 7$ and between intravenous and nasogastric enrichments were tested by paired $t$ test.

\section{RESULTS}

Thirty-eight infants were included in the study, 14 in group C, 12 in group BM, and 12 in group F. Clinical details of the patients are given in Table 1. The gestational age of patients receiving breast milk was lower compared with infants receiving formula, whereas more infants in the group receiving formula were small for gestational age. Fewer patients in the

Table 1. Clinical characteristics of the infants

\begin{tabular}{lccc}
\hline \multicolumn{1}{c}{ Characteristic } & $\begin{array}{c}\text { Total parenteral nutrition } \\
\text { group }(n=14)\end{array}$ & $\begin{array}{c}\text { Parenteral nutrition }+ \\
\text { breastmilk group }(n=12)\end{array}$ & $\begin{array}{c}\text { Parenteral nutrition }+ \\
\text { formula group }(n=12)\end{array}$ \\
\hline Birth weight (g) & $1366 \pm 240$ & $1252 \pm 235$ & $1300 \pm 231$ \\
Gestational age (wk) & $31 \pm 2$ & $29 \pm 1^{*}$ & $32 \pm 2 *$ \\
SGA (no./total no.) & $1 / 14$ & $0 / 12^{*}$ & $6 / 12^{*} \dagger$ \\
Male sex [no. (\%)] & $9(64)$ & $5(42)$ & $7(58)$ \\
CRIB score & $4 \pm 3$ & $4 \pm 5$ & $1 \pm 1$ \\
On ventilation (no./total no.) & $5 / 14$ & $4 / 12$ & $1 / 12$ \\
Antenatal steroids (no./total no.) & $6 / 14$ & $10 / 12 \dagger$ & $10 / 12 \dagger$ \\
Caloric intake d 1 & $24 \pm 9$ & $20 \pm 9$ & $27 \pm 19$ \\
Caloric intake d 7 & $77 \pm 15$ & $76 \pm 10$ & $71 \pm 11$ \\
Nitrogen intake d 7 (mg/kg/d) & $386 \pm 86$ & $385 \pm 9$ & $367 \pm 31$ \\
\hline
\end{tabular}

Values are mean \pm SD. SGA, small for gestational age; CRIB, clinical risk index for babies.

* Statistically different at $p<.05$ between the breast milk and the formula group.

$\dagger$ Statistically different from the control group. 
control group received antenatal corticosteroids compared with the other two groups. No other differences between groups were observed.

The aim of giving $20 \mathrm{~mL} / \mathrm{kg} / \mathrm{d}$ was reached in the formula group on $\mathrm{d} 3$ and on $\mathrm{d} 4$ in the group receiving breast milk. No difference between intake in the enterally fed groups was observed on $\mathrm{d} 4,5,6$, and 7 . There was no difference in daily parenteral amino acid nor energy intake between the groups on any day. Weight gain, measured as weight above birth weight on postnatal d 21, and tolerance of enteral feedings, measured as the age at which infants tolerated 120 or $150 \mathrm{~mL} / \mathrm{kg} / \mathrm{d}$ was not different between groups (Table 2).

There was no difference in nitrogen intake, nitrogen excretion, or nitrogen balance between groups at either $\mathrm{d} 1$ or $\mathrm{d} 7$. Nitrogen balance was negative in all groups at $\mathrm{d} 1(-70 \pm 21$, $-66 \pm 35$, and $-95 \pm 35 \mathrm{mg} / \mathrm{kg} / \mathrm{d}$ in groups $\mathrm{C}, \mathrm{BM}$, and $\mathrm{F}$, respectively), to become positive on $\mathrm{d} 7(229 \pm 73,206 \pm 111$, and $247 \pm 36 \mathrm{mg} / \mathrm{kg} / \mathrm{d}$ in the three groups, respectively).

In all studies, a plateau in isotope enrichment was observed after the intravenous as well as the nasogastric infusion. The variability in plasma enrichment was higher for the nasogastric compared with the intravenous tracer. Plateau values were determined by visual inspection and confirmed by regression analysis as a slope not significantly different from zero. The data were expressed as mol percentage enrichment.

On d 1, no difference in leucine enrichment between nasogastric and intravenous tracer was observed in any of the groups; the KIC enrichment was significantly higher for the intravenous tracer compared with the nasogastric tracer in all three groups (Fig. 2, $A$ and $B$ ).

On d 7, leucine enrichment between nasogastric and intravenous tracer was not different in the control group, whereas the enrichment was significantly lower for the nasogastric tracer in groups BM and F; KIC enrichment gave the same results, no difference between intravenous and nasogastric tracer in group $\mathrm{C}$ and a significantly lower enrichment for the nasogastric tracer in groups BM and F (Fig. 2, $A$ and $B$ ). In all three groups, the leucine enrichment as well as the KIC enrichment was lower for both tracers on $\mathrm{d} 7$ compared with $\mathrm{d}$ 1. The protein turnover, calculated from the plasma enrichment, is given in Figure 3. On d 1, the flux calculated from the intravenous tracer was lower compared with the nasogastric flux in all groups. On d 7, the intravenous flux was significantly lower than the nasogastric flux in both groups receiving minimal enteral feeding. The leucine extraction by splanchnic tissue is given in Figure 4. The leucine extraction was not significantly different between the three groups on $\mathrm{d} 1$. On $\mathrm{d} 7$, the splanchnic leucine extraction increased in both groups receiving minimal enteral nutrition but decreased in the control

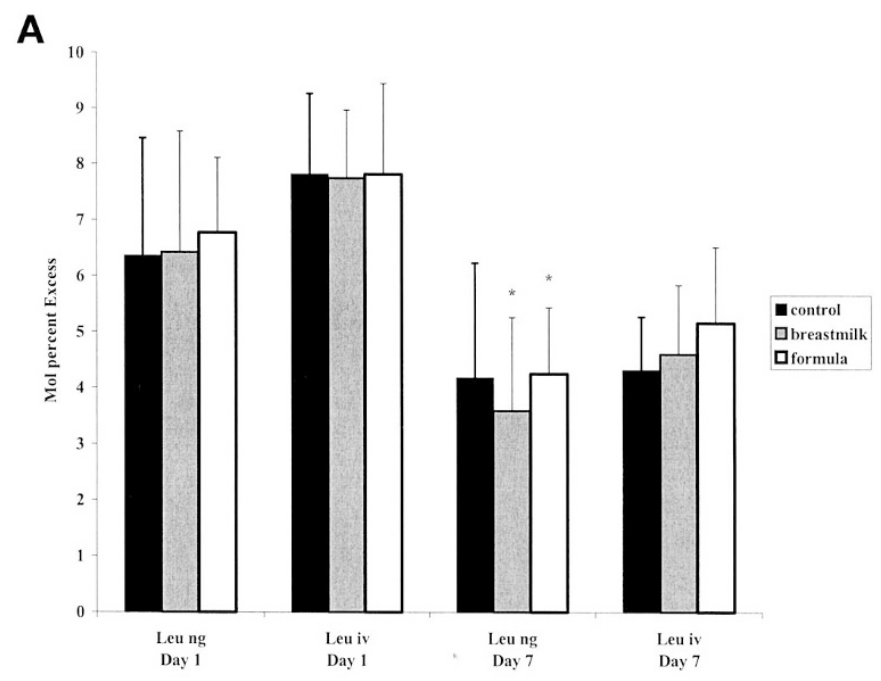

\section{B}

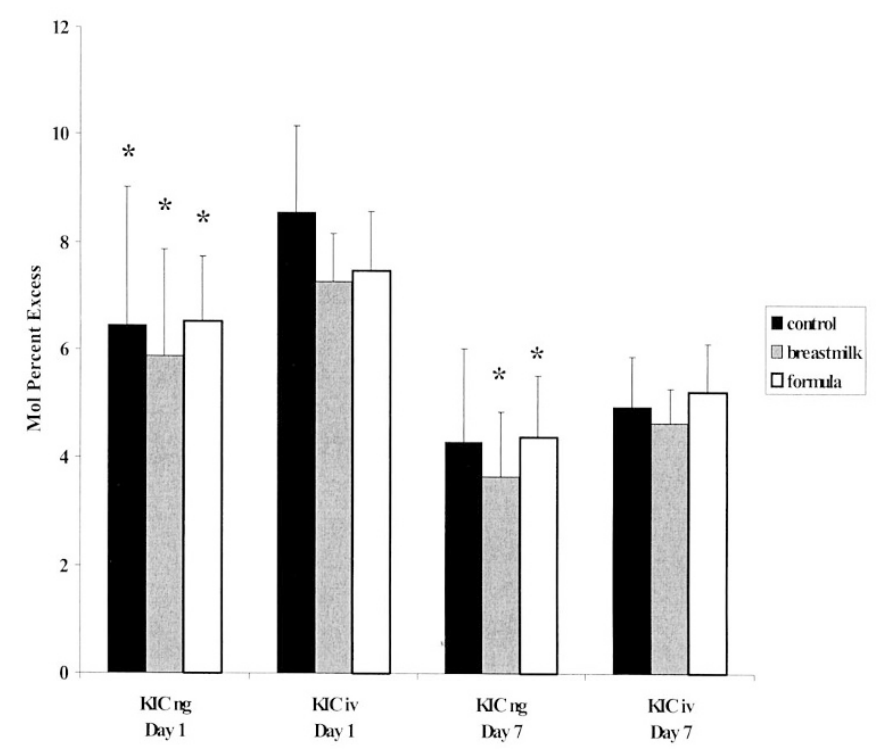

Figure 2. (A) Plasma leucine enrichment, mean $\pm \mathrm{SD}$. *Statistically different at $p<0.05$ vs. i.v. plasma leucine enrichment day 7. (B) Plasma KIC enrichment, mean $\pm \mathrm{SD}$. *Statistically different at $p<0.05$ vs. i.v. plasma KIC enrichment the same day. n.g., tracer given via nasogastric tube; i.v., tracer given intravenously.

group. Because of the rather large SD, the differences in the control group did not reach significance.

The release of leucine from proteins (a measure for protein breakdown) based on plasma $\left[{ }^{13} \mathrm{C}\right] \mathrm{KIC}$ and $\left[{ }^{2} \mathrm{H}_{3}\right] \mathrm{KIC}$ enrichment was not different on $\mathrm{d} 1$ between the three groups, either for the nasogastric tracer $(262 \pm 144,268 \pm 105$, and $215 \pm$

Table 2. Clinical outcomes

\begin{tabular}{lccc}
\hline & Total parenteral nutrition \\
Outcome & group $(n=14)$ & $\begin{array}{c}\text { Parenteral nutrition }+ \\
\text { breastmilk group }(n=12)\end{array}$ & $\begin{array}{c}\text { Parenteral nutrition }+ \\
\text { formula group }(n=12)\end{array}$ \\
\hline Weight above birth weight at d $21(\mathrm{~g})$ & $190 \pm 132$ & $155 \pm 94$ & $221 \pm 162$ \\
Age infants tolerate $120 \mathrm{~mL} / \mathrm{kg} / \mathrm{d}$ enteral feeding (d) & $16 \pm 4$ & $14 \pm 6$ & $13 \pm 2$ \\
Age infants tolerate $150 \mathrm{~mL} / \mathrm{kg} / \mathrm{d}$ enteral feeding (d) & $17 \pm 5$ & $18 \pm 8$ & $16 \pm 2$ \\
\hline
\end{tabular}

Values are mean \pm SD. 


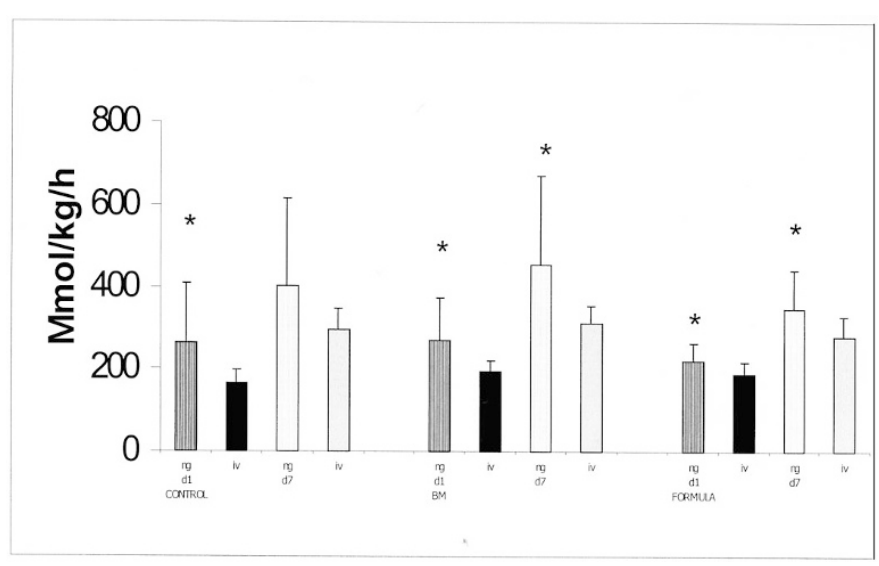

Figure 3. Leucine turnover calculated from plasma KIC enrichment, mean \pm SD. *Statistically different at $p<0.05$ vs. flux calculated from the i.v. given tracer plasma enrichment. n.g., tracer given via nasogastric tube; i.v., tracer given intravenously.

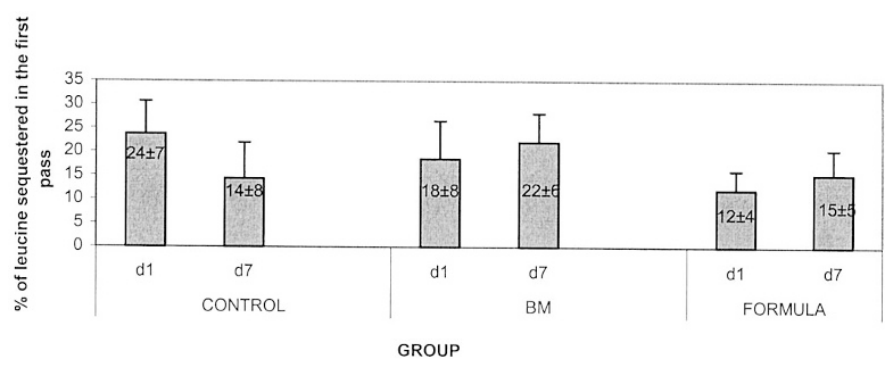

Figure 4. Leucine splanchnic extraction, mean \pm SEM.

$46 \mu \mathrm{mol} / \mathrm{kg} / \mathrm{h}$ for groups $\mathrm{C}, \mathrm{BM}$, and $\mathrm{F}$, respectively), or the intravenous tracer $(158 \pm 27,193 \pm 27$, and $183 \pm 41$ $\mu \mathrm{mol} / \mathrm{kg} / \mathrm{h}$ in the three groups). The release of leucine from proteins at $\mathrm{d} 7$ was also not different between the three groups measured from the plasma enrichment of either the nasogastric or intravenous tracer. Pooling the data of the three groups together, we found a statistically significant higher leucine release from protein on d $7(206 \pm 40)$ versus d 1 (178 \pm 35 $\mu \mathrm{mol} / \mathrm{kg} / \mathrm{h})(p=0.0025)$.

Because of technical problems with $\mathrm{CO}_{2}$ collection, reliable data on NOLD, a reflection of the amount of leucine that is being used for protein synthesis, could only be obtained in seven infants in group $\mathrm{C}$, four intubated on $\mathrm{d} 1$ and all extubated on $\mathrm{d} 7$, and in five infants in each of the other two groups, BM and F. Two infants in the BM group were intubated on $\mathrm{d} 1$ and only one in the F group. On $\mathrm{d} 7$, all patients in these two groups were extubated except for one in the BM group. NOLD increased in all groups from d 1 to $\mathrm{d} 7$ (228 \pm 141 at birth versus $357 \pm 234,228 \pm 107$ versus $338 \pm 190$, and $183.5 \pm 57$ versus $292 \pm 121 \mu \mathrm{mol} / \mathrm{kg} / \mathrm{h}$ in groups C, BM, and F, respectively. No differences were observed between the three groups on $\mathrm{d} 1$ or $\mathrm{d} 7$.

\section{DISCUSSION}

In this study, we have shown that in preterm infants 5-6 d of enteral feeding of $20 \mathrm{mg} / \mathrm{kg} / \mathrm{d}$ gives a lower plasma enrichment of a leucine tracer given orally compared with the plasma enrichment of a tracer given intravenously, indicating leucine uptake by splanchnic tissues. No difference between plasma leucine or KIC enrichment from the two tracers in plasma was found in infants who did not receive any enteral feeding.

Small amounts of feeding, also called trophic feeding, are used to promote the maturation of the gastrointestinal tract. Whether trophic feeding in preterm infants has a positive effect on splanchnic protein turnover is unknown. We evaluated the protein turnover of the splanchnic tissues from the uptake of leucine by the gastrointestinal tract. We used a double tracer infusion of leucine, administered simultaneously through the nasogastric and intravenous route, as described by Hoerr et al. (8). At the same time, our studies are hard to compare with those performed so far with this dual tracer method. Hoerr et al. (8) compared in a short-term crossover design the difference in splanchnic uptake of leucine between the fed and postabsorptive state in adult humans. Matthews et al. (11) investigated the fate of enterally delivered leucine in the postabsorptive state in adult humans. Beaufrère et al. (9) used this method in VLBW infants to study the first-pass splanchnic extraction of enterally delivered leucine in the fed state.

In our study, we were interested in the effect of minimal enteral feeding on the splanchnic uptake of leucine. The amount of feeding given is very low and of no importance nutritionally. Moreover, we stopped the minimal enteral feeding in all groups $5 \mathrm{~h}$ before the tracer study. At the same time, parenteral nutrition was continued. It is therefore difficult to compare our results with previously published results in either the fed or postabsorptive state. We hypothesized that minimal enteral feeding would have a positive effect on the splanchnic uptake of leucine, resulting in a lower enrichment of leucine and KIC from the nasogastric than the intravenous tracer. On $\mathrm{d}$ 1, we observed a lower $\mathrm{KIC}$ enrichment for the nasogastric compared with the intravenous tracer, indicating uptake of amino acids in the splanchnic tissues. For leucine, the difference was in the same direction but not significant. On d 7, in both groups receiving minimal enteral feeding, the enrichment for the nasogastric tracer was lower than the intravenous tracer both for leucine and KIC. In contrast, in the control group, there was no difference in enrichment, neither for leucine or $\mathrm{KIC}$, between the nasogastric and intravenous tracer. The lower enrichments for the nasogastric tracer indicated that leucine is taken up in the first pass in the groups receiving minimal enteral feeding but not in the control group.

Because of the availability of breast milk in the first days after birth, the cumulative enteral intake was higher in the formula group than in the breast milk group. Also, infants in the F group were older, and more were small for gestational age. The higher difference between nasogastric and intravenous tracer on d 1 in this group, compared with the other groups, might be related to the clinical differences between groups.

We speculate that results on $\mathrm{d} 1$ can be explained by the positive effect of amniotic fluid on the maturation of the GI tract. In the fetus, it is estimated that nutrients absorbed from amniotic fluid provide $10-15 \%$ of fetal requirements for energy and nutrients (21). Our studies on d 1 might reflect the intrauterine situation.

Different studies have estimated the splanchnic uptake of leucine. Beaufrère et al. (9) found in enterally fed newborn 
infants a splanchnic uptake during the first pass of $48.2 \pm$ $15.6 \%$ of the enterally administered leucine. Kien et al. (22) found an uptake of $16 \pm 11.2 \%$ in CF patients and $24.4 \pm$ $25.6 \%$ in controls. Studies in adults have shown uptakes from $17 \%$ to $25 \%$. In this study, we found an uptake in first pass in all groups of approximately $20 \%$ on d 1 of life and also in the groups receiving minimal enteral nutrition on $d 7$. In the control group, however, the percentage decreased to $10 \%$ on $\mathrm{d}$ 7. Because of the rather large SD, the difference between $d 1$ and $\mathrm{d} 7$ in the control group did not reach significance. A large variation in the splanchnic uptake was also observed by Kien et al. (22) in older children, and might be the result of the calculation of splanchnic uptake where the variation in both the measurement of the intravenous and nasogastric tracer enrichment is combined. As the amount of protein given nasogastrically is much less than in the study of Beaufrére, this can explain why, in our study, the difference between nasogastric and intravenous tracer enrichment in plasma is much lower than in their study.

Antenatal corticosteroids might have an effect on splanchnic uptake of leucine. Fewer patients in the control group received antenatal corticosteroids compared with the feeding groups. There was no difference between the groups on $d 1$. The differences found on d 7 might have been influenced by antenatal corticosteroids. We compared the results of only those patients who received antenatal steroids in the three groups. The results remained significantly different between groups.

$\mathrm{KIC}$ is formed within the cell from leucine and is considered a reliable marker for intracellular leucine enrichment $(20,23$, 24). In all studies, we observed a KIC-leucine enrichment ratio of around 1 for both tracers.

KIC formed within the enterocyte can either be released as KIC, oxidized, or converted to leucine. Matthews et al. (24) recently measured the fate of enterally administered KIC in healthy human adults. They found that only $5 \%$ of the enterally administered $\mathrm{KIC}$ is oxidized in the first pass, whereas $84 \%$ is oxidized if converted to leucine. This might indicate that KIC produced in the enterocyte is mainly used as leucine for protein synthesis.

In our study, we did not aim to quantitate the protein turnover of splanchnic tissue. Our aim was to evaluate whether minimal enteral feeding has a positive effect on the maturation of the GI tract as indicated by increased splanchnic uptake of leucine.

Because of technical problems with the $\mathrm{CO}_{2}$ collection, we could measure ${ }^{13} \mathrm{CO}_{2}$ excretion only in approximately $50 \%$ of the infants studied. On d 1, only $20 \%$ of the enterally delivered tracer was excreted as $\mathrm{CO}_{2}$, and $30 \%$ on $\mathrm{d} 7$. This indicates that $70-80 \%$ of the enterally delivered leucine is used for protein synthesis. Unfortunately, the fate of the sequestered leucine cannot be deducted from this study. A crossover study with ${ }^{13} \mathrm{C}$ leucine given orally and intragastrically was not performed because of the prolonged duration needed for that study and the risk of recycling (11). Leucine and KIC enrichments are much lower (both from the nasogastric and intravenous tracer) on $\mathrm{d}$ 7 compared with $d 1$. This can be explained by the difference in protein intake between both study days (25-27).
To our knowledge, this is the first study in VLBW infants that evaluates the effect of enteral nutrition on splanchnic protein metabolism. Even when parenteral nutrition provides adequate nutritional intake, splanchnic uptake and probably splanchnic protein synthesis are impaired. This study shows that feeding very small volumes of nutrient improves splanchnic uptake.

In our study, either because of the small sample size or the amount of feeding given, we did not find a difference in clinical outcome parameters (weight gain, time to reach full enteral feeding) between groups. Infants were on full enteral feeding at the mean age of $16 \mathrm{~d}$, earlier than in most published studies.

\section{CONCLUSION}

Our results indicate that minimal enteral feeding - even in low volumes of $20 \mathrm{~mL} / \mathrm{kg} / \mathrm{d}$ - improves maturation of splanchnic tissue as evidenced by an increase in leucine uptake. More studies are needed to define the optimal amount and composition of minimal enteral nutrition.

Acknowledgments. The authors thank Sagrario Lara, Rosa Codoceo, and Villar Palasí for excellent technical assistance, and the staff of the Neonatal Intensive Care Unit at La Paz University Hospital for their help in carrying out these studies.

\section{REFERENCES}

1. Levine GM, Deren JJ, Steiger E, Zinno R 1974 Role of oral intake in maintenance of gut mass and disaccharide activity. Gastroenterology 67:975-982

2. Hughes CA, Dowling RH 1980 Speed of onset of adaptive mucosal hypoplasia and hypofunction in the intestine of parenterally fed rats. Clin Sci (Colch) 59:317-327

3. Chance WT, Foley Nelson T, Thomas I, Balasubramaniam A 1997 Prevention of parenteral nutrition-induced gut hypoplasia by coinfusion of glucagon-like-peptide- 2 . Am J Physiol 273:G559-G563

4. Peterson CA, Carey HV, Hinton PL, Lo HC, Ney DM 1997 GH elevates serum IGF-1 levels but does not alter mucosal atrophy in parenterally fed rats. Am J Physiol 272:G1100-G1108

5. Chance WT, Zhang X, Balasubramaniam A, Fisher JE 1996 Preservation of intestine protein by peptide YY during total parenteral nutrition. Life Sci 58:1785-1794

6. Berseth CL 1992 Effect of early feeding on maturation of the preterm infant's small intestine. J Pediatr 120:947-953

7. Berseth CL, Nordyke C 1993 Enteral nutrients promote postnatal maturation of intestinal motor activity in preterm infants. Am J Physiol 264:G1046-G1051

8. Hoerr RA, Matthews DE, Bier DM, Young VB 1991 Leucine kinetics from $\left[{ }^{2} \mathrm{H}_{3}\right]$ and $\left[{ }^{13} \mathrm{C}\right]$ leucine infused simultaneously by gut and vein. Am J Physiol 260:E111E117

9. Beaufrère B, Fournier V, Salle B, Putet G 1992 Leucine kinetics in fed low birth weight infants: importance of splanchnic tissues. Am J Physiol 263:E214-E220

10. Biolo G, Tessari P, Inchiostro S, Bruttomesso D, Fongher C, Sabadin L, Fratton MG, Valerio A, Tiengo A 1992 Leucine and phenylalanine kinetics during mixed meal ingestion: a multiple tracer approach. Am J Physiol 262:E455-E462

11. Matthews DE, Marano MA, Campbell RG 1993 Splanchnic bed utilization of leucine and phenylalanine in humans. Am J Physiol 264:E109-E118

12. Biolo G, Tessari P 1997 Splanchnic versus whole-body production of $\alpha$-ketoisocaproate from leucine in the fed state. Metabolism 46:164-167

13. Cortiella J, Matthews DE, Hoerr RA, Bier DM, Young VR 1988 Leucine kinetics at graded intakes in young men: quantitative fate of dietary leucine. Am J Clin Nutr 48:998-1009

14. Cayol M, Boirie Y, Rambourdin F, Prugnaud J, Gachon P, Beaufrére B, Obled CH 1997 Influence of protein intake on whole body and splanchnic leucine kinetics in humans. Am J Physiol 272:E584-E591

15. Boirie Y, Gachon P, Beaufrére B 1997 Splanchnic and whole-body kinetics in young and elderly men. Am J Clin Nutr 65:489-495

16. Ballard JL, Khoury JC, Wedig K, Wang L, Eilers-Walsman BL, Lipp R 1991 New Ballard score, expanded to include extremely premature infants. J Pediatr 119:417423

17. Usher RH, McLean F 1969 Intrauterine growth of live born Caucasian infants at sea level: standards obtained from measurements in 7 dimensions of infants born between 25 and 44 weeks of gestation. J Pediatr 74:901-910

18. The International Neonatal Network 1993 The CRIB (clinical risk index for babies) score: a tool for assessing initial neonatal risk and comparing performance of neonatal intensive care units. Lancet 342:193-198 
19. VanGoudoever JB, Sulkers EJ, Halliday D, Degenhart HJ, Carnielli VP, Wattimena JLD, Sauer PJ 1995 Whole body protein turnover in preterm AGA and SGA infants: comparison of $\left[{ }^{15} \mathrm{~N}\right]$ glucine and $\left[1-{ }^{13} \mathrm{C}\right]$ leucine administered simultaneously. Ped Res 37:381-388

20. Schwenk WF, Beaufrère B, Haymond MW 1985 Use of reciprocal pool specific activities to model leucine metabolism in humans. Am J Physiol 246:E646-E650

21. Buddington RK 1994 Nutrition and ontogenic development of the intestine. Can J Physiol Pharmacol 72:251-259

22. Kien CL, Horswill CA, Zipf WB, McCoy KS, Denne SC 1999 Splanchnic uptake of leucine in healthy children and in children with cystic fibrosis. Pediatr Res 45:680683

23. Matthews DE, Schwarz HP, Yang RD, Motil KJ, Young VR, Bier DM 1982 Relationship of plasma leucine and $\alpha$-ketoisocaproate during a $\mathrm{L}-\left[1-{ }^{13} \mathrm{C}\right]$ leucine infusion in man: a method for measuring human intracellular leucine tracer enrichment. Metabolism 31:1105-1112

24. Matthews DE, Harkin R, Battezzati A, Brillon DJ 1999 Splanchnic bed utilization of enteral alpha-ketoisocaproate in humans. Metabolism 48:1555-1563

25. Van Goudoever JB, Colen T, Wattimena JL, Huijmans JG, Carnielli VP, Sauer PJ 1995 Immediate commencement of amino acid supplementation in preterm infants: effect on serum amino acid concentrations and protein kinetics on the first day of life. J Pediatr 127:458-465

26. Rivera A, Bell EF, Bier DM 1993 Effect of intravenous amino acids on protein metabolism of preterm infants during the first three days of life. Pediatr Res 33:106-111

27. Mitton SG, Garlick PJ 1992 Changes in protein turnover after the introduction of parenteral nutrition in premature infants: comparison of breast milk and egg proteinbased amino acid solutions. Pediatr Res 32:447-454 